\title{
PROJECT RISK MANAGEMENT OF ELECTRICAL SWITCHBOARD DELIVERY
}

\author{
Dorota Kuchta*, Ewa Ptaszyńska**
}

\begin{abstract}
Background. In projects of electrical switchboard delivery we can identify many risks which are usually quite severe in their consequences, because these projects are high-budget projects. Our studies indicate that there are no formalised risk management procedures in many Polish companies that realise such projects.
\end{abstract}

Research aims. Therefore we propose using a traditional risk management procedure adapted for projects of electrical switchboard delivery what was verified on the example of a selected company.

Methodology. We use the following research methods: analysis of the documentation relating to completed projects of electrical switchboard delivery, interviews with project managers, and literature studies.

Key findings. We obtained the following results: Work Breakdown Structure (WBS), list of identified project risks, list of risk responses, computer tool for managing identified risks in projects of electrical switchboard delivery. Based on the completed studies we can state that risk management is an important element of electrical switchboard delivery and should not be ignored in companies that realise such projects.

Keywords: project management, risk management, projects of electrical switchboard delivery.

\section{INTRODUCTION}

In this article we propose a risk management procedure in projects of electrical switchboard delivery. Risk is defined here as an event, which occurrence is possible, and if it happens it creates a possibility

* Wroclaw University of Technology. E-mail: dorota.kuchta@pwr.edu.pl

** Wroclaw University of Technology. E-mail: ewa.ptaszynska@pwr.edu.pl 
that a project's completion will be extended, the cost will increase or the final product will not be compatible with the plan and deviations from the plan in at least one of these three aspects will be difficult, if not impossible to accept (Courtot, 1998).

In Poland there are about 20 to 30 companies which realise projects of electrical switchboard delivery, for example ZPUE Katowice S.A., Taurus-Technic Sp. z o.o., ELSTA Sp. z o.o., Hulanicki Bednarek Sp. z o.o., and others. Based on literature studies and interviews with employees of these companies we state that there are often no formalised risk management procedures in projects of electrical switchboard delivery. Therefore this article contains a proposal of risk management procedure in projects of electrical switchboard delivery and describes a computer tool supporting it. We conducted 10 in-depth interviews. The main goal of performing the interviews was to define project risk management procedure for those projects. We built a list of 15 questions. Additionally, interviewees could also add their own comments. The interviewees were people involved in projects of electrical switchboard delivery, i.e. suppliers, technicians, or project managers. Conducting the interview took about $1 \mathrm{~h}$. The projects that were taken into account for the interviews were the projects with a budget between EUR 100,000 and EUR 2,000,000.

\section{General facts about risk management}

There are many definitions of risk presented in literature. It is believed that A. H. Willett provided the first definition of risk in 1901 in which risk was described as objectified uncertainty of unwanted event occurring (Willett, 1901). J. Pfeffer defines risk as a combination of hazardous elements measured by probability and H. Maylor describes risk as a probability of damages and losses (Maylor, 1996). Another definition of risk was proposed in the context of uncertainty. W.F. Samuelson and S.G. Marks claim that risk occurs when there is more than one possible effect of our decision. To be more precise, we can state that with a greater dispersion of results we have a greater degree of uncertainty (Samuelson \& Marks, 2006). Originally risk management was a part of insurance management. Over the years insurance has been reduced to the role of risk management instruments and risk management itself has become to be seen more widely. Y.Y. Chong states that appropriate risk management reduces the probability of 
achieving bad results in business, commonly attributed to bad luck (Brown \& Chong, 2000).

According to F.R. Kaen risk management in enterprises is particularly recommended for increasing probability of successful implementation of projects (Kaen, 2000). Then we talk about project risk. It is important to separate project risk from organisational risk which is closely associated with the business goal of the project. In this paper, as it was underlined in the Introduction, we focus on the definition of risk delivered by $\mathrm{H}$. Courtot (1998). Project risk is defined as an uncertain event or, in other words, a condition that, if risk occurs, it has a meaningful effect on one or more project's objectives. Project risk can have a positive or negative impact on the project. The former is treated as an opportunity and the latter as a threat. The main objective of project risk management is to identify risks in the project, provide their measurement and finally to develop appropriate risk responses. Therefore, project risk management should be a purposeful, planned, systematic, and long-term process (Zachorowska, 2006).

In conclusion, it should be emphasised that the project risk management process should be carried out continuously, i.e. starting from the initiation and planning through the execution phase of the project until its completion. There are many concepts of project risk management that distinguish different phases of the risk management process (including: Davidson, 1995; Forsbery, Mooz \& Cotterman, 1996; Kaczmarek, 2006; Kleim \& Ludin, 1997; PMI, 2008; Pritchard, 2012; Rogowski \& Michalczewski, 2005; Trocki \& Grucza, 2007). In this paper we focus on the concept proposed by the Project Management Institute, which lists the following main sub-processes in the risk management process: planning risk management process, risk identification, qualitative risk analysis (risk classification), quantitative risk analysis (quantification of the risk), planning how to respond to the risk, risk monitoring, and risk control (PMI, 2008).

\section{Projects of electrical switchboard delivery}

Electrical switchboards are devices or groups of devices, which main purpose is to distribute electricity as well as to bond and protect circuits and appliances. The components of an electrical switchboard are 
primarily: protection, metering, control and signalling apparatuses; busbars; insulating parts; mechanical engineering; covers. There are three types of switchboards: low, medium, and high voltage. We focus on delivery projects of low-voltage electrical switchboards, but they can be divided into different types. For example, taking into account the customer, we can distinguish two project types: projects implemented for customers from Europe and projects implemented for customers from the Middle East. Projects realised for customers from the Middle East are more risky, because of communication problems resulting from cultural differences. In this paper we focus on projects of low-voltage switchboards, implemented for customers from the Middle East.

Based on interviews with the Project Manager in projects of electrical switchboard delivery, we discovered that in the company there is no project risk management procedure being used, as well as there is no Work Breakdown Structure (WBS) being created. Therefore in the first step of our analysis the WBS for such a type of project was distinguished and documented (Figure 1). We defined three main stages during realising projects of electrical switchboard delivery which were then divided into tasks.

The first stage is switchboard engineering which is not always performed by the company carrying out the project. In many cases a customer ordering a switchboard prepares project documentation independently. When the company is responsible for this stage the following tasks must be performed:

1.1. Load list analysis. A load list contains the elements which consume electricity. Examples in households are: electric stove, washing machine, iron etc. Based on the load list analysis appropriate protection is selected.

1.2. Equipment list preparation. After analysing the load list, the devices to protect and control must be selected. Selected devices need to be compatible with each other. It is a very time-consuming task.

1.3. Wiring diagrams preparation. After preparing a list of the necessary equipment, the next task is wiring diagrams' preparation. These diagrams are later used by the installer, electrician, and others involved in the switchboard's construction process. It is the most time-consuming task. Moreover, in this task mistakes are made very often, which can cause considerable inconveniences later. 


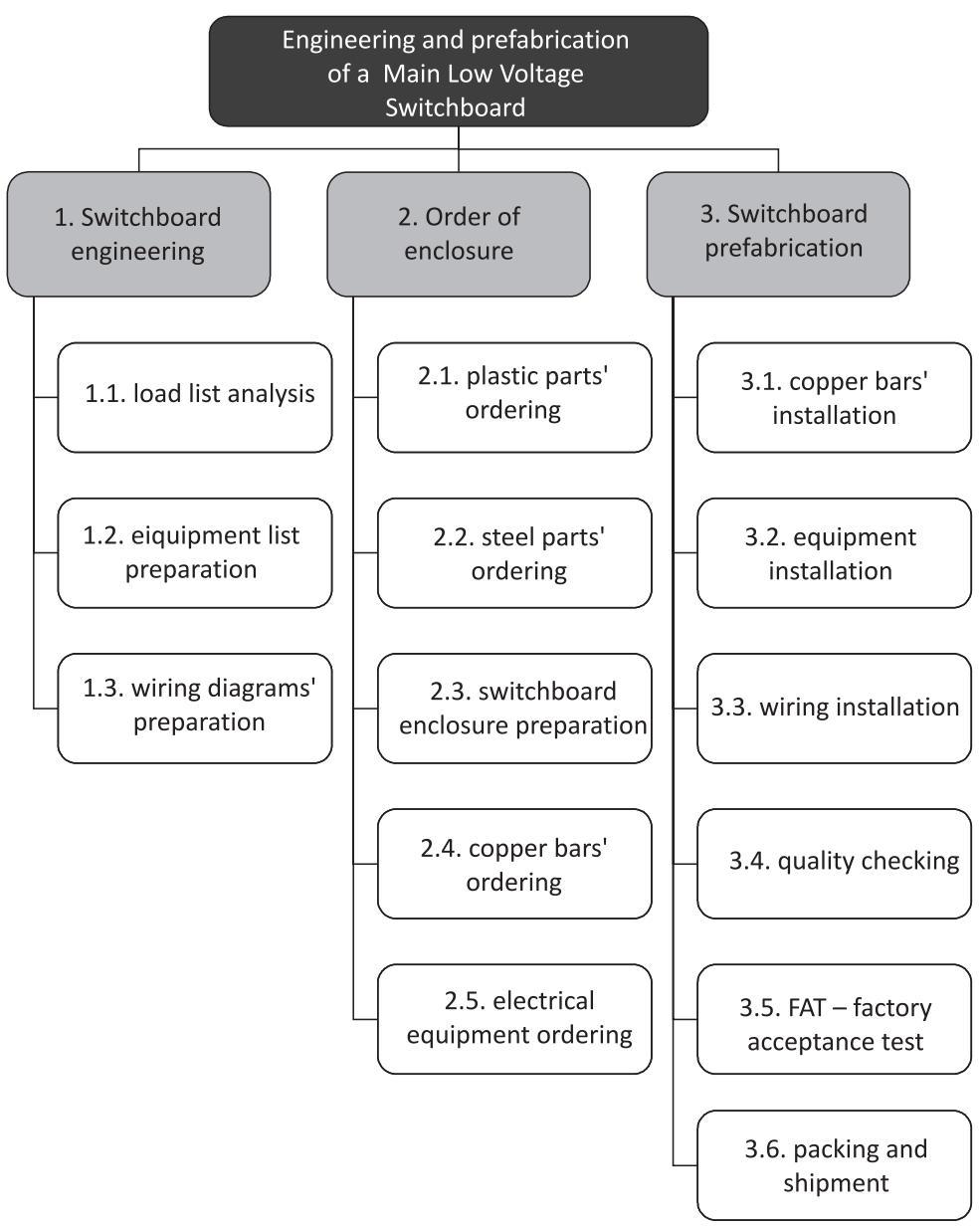

Figure 1. Work Breakdown Structure in projects of electrical switchboard delivery

Source: own elaboration.

The second stage during the realisation of projects of electrical switchboard delivery is to order the enclosure and electrical equipment based on prepared wiring diagrams. In this stage the following tasks must be performed:

2.1. Plastic parts' ordering. The switchboard includes i.a. plastic parts, which are relatively expensive components of the whole panel. Besides, it is very difficult to find their replacements. At the moment they are delivered by Siemens, located in Leipzig. Most Polish companies cannot buy these items on their own, 
because the license agreement with Siemens does not allow it. The waiting time for plastic parts is approximately from three to four weeks.

2.2. Steel parts' ordering. An example of steel parts in the switchboard are its walls, brackets, or mounting plates. These elements are manufactured and powder painted (in the colour chosen by the customer) i.e. by ZPAS S.A. The average duration of steel parts' order completion is four weeks.

2.3. Switchboard enclosure preparation. After completing the plastic and metal parts, their installation is performed. This task is also performed by ZPAS S.A. and takes about one week, but it depends on the size of the switchboard.

2.4. Copper bars' ordering. Copper bars must be placed in each switchboard. They serve as the grounding. Copper bars can be produced independently or supplied by subcontractors. Copper bars are performed using specialised equipment, which is able to bend and cut any shape from a straight copper bar. After that, the prepared copper bars are installed in the switchboard enclosure supplied by ZPAS S.A. - task 3.1. which usually takes about one week (time may be extended or shortened depending on the size of the switchboard).

2.5. Electrical equipment ordering. Based on the load list analysis in the switchboard, the Technologist creates a list of electrical equipment which needs to be ordered. After that the Purchasing Department presents the best supplier offers for a specific equipment. Then the Project Manager selects one offer, depending on the time of the contract, costs, payment methods, delivery conditions, etc. In the analyzed company, approximately $60 \%$ of the orders are implemented by Siemens, because due to permanent and long-term cooperation they have a competitive offer and constant price discounts. The average time of electrical equipment delivery is from four to five weeks. Switchboard enclosure preparation lasts much longer than ordering and delivery of electrical equipment, so the company has time to collect competitive offers from the suppliers.

The third stage during realising of the projects of electrical switchboard delivery is switchboard prefabrication. After completing the main elements of a switchboard such as the enclosure, electrical equipment, 
copper bars, the prefabrication of the switchboard can be started. In this stage the following tasks must be performed:

3.1. Copper bars' installation. Ironworkers install copper bars in the switchboard enclosure supplied by ZPAS S.A. Copper bars ale always installed in the beginning, before fitting in the other devices.

3.2. Equipment installation. The customer usually specifies not only switchboard appearance (e.g. its colour), but also determines what kind of protection, metering, control or indicator apparatus must be placed in the switchboard. Based on it the other devices are installed, which were presented in the initial project specifications.

3.3. Wiring installation. It is the process of connecting wires between electrical devices. Based on the prepared wiring diagrams, the Electrician connects the wires. Wiring installation is the most time-consuming task throughout the whole project. A typical electrical switchboard has approximately 4,000 connections to be made and one Electrician is able to carry out about 100-120 connections per day. This process cannot be accelerated by involving more Electricians, because often only one person can work with one switchboard. Working in the shift mode also does not give the desired results, because the person who starts the second shift would need at least two hours to analyse what has been done so far.

3.4. Checking quality. After wiring the installation project is transferred to the Quality Control Department that consists of engineers who check if connections are made correctly and that there are no aesthetic mistakes. They can also find mistakes made during the wiring diagrams preparation. The Quality Control Department prepares a list of identified mistakes, which is sent to the Electrician who was responsible for the switchboard. The Electrician corrects the mistakes and the Quality Control Department checks the project again, but it only verifies those elements that need to be improved. Finally, when there are no more mistakes, the switchboard is checked for its operationality.

3.5. Factory Acceptance Test (FAT). In the case of long-term cooperation with the customer FAT can be omitted. But more often this task is an essential part of the project. The Project 
Manager, the Quality Control Department and the Customer are involved in these tests. During this meeting everyone has the right to submit their comments, which are then written up as a list. Costs of improvements in the project depend on whether there are errors on the part of the contractor or errors due to reasons attributable to the customer or the revised concept. Usually, an additional time to make these improvements is provided in the project schedule.

3.6. Packing and shipment. There are two basic types of packing electrical switchboards:

- package for sea transportation - in this case switchboards are packed in air-tight aluminium foil and dehumidifiers are installed in the package. The wrapped switchboards are placed on a pallet in a wooden box;

- package for road transportation - in this case the switchboard is placed on a pallet and wrapped with foil and transported to the customer by rented truck. If shipping is outside of the European Union, the cost of customs clearance needs to also be taken into account.

\section{METHOD}

The proposed procedure for risk management in projects of electrical switchboard delivery is shown in Figure 2. The procedure was implemented in .NET/C\# technology stack (Troelsen, 2012).

In the beginning we have to select the type of project to be analysed. The second step is to select the task (according to the WBS shown in Figure 1) for risk analysis. Based on the interviews with the Project Manager of electrical switchboard delivery, we recommend a risk analysis for each task in the project. The third step in the proposed procedure is to identify risks in the selected task. The fourth step is to assess probability and consequences of the identified risk. If the assessment is carried out for the first time, the Project Manager has to estimate risk probability (by using the words "small", "medium", or "high") and its consequences (by using the words "weak", "medium", "severe"). In other cases the assessment is generated automatically. For this purpose verbal expressions are converted into numbers as follows: "small" /"weak" = 0; "medium" = 0.5; "high"/"severe" = 1 . Then, 
the assessment is generated based on average post factum assessments from two past completed projects (learning through experience). Finally, there is a conversion of the number obtained into verbal expression according to the following rules: $<0 ; 0.25>=$ "small" "weak", $(0.25$, 0.75) = "medium", M, <0.75; 1 = "high"/"severe" (Ptaszyńska, 2012).

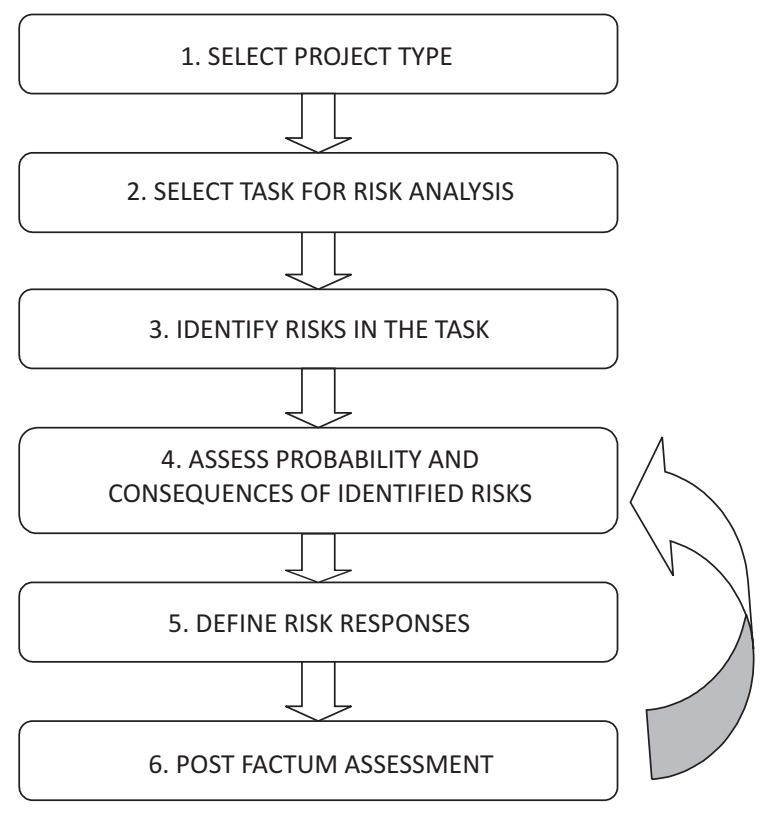

Figure 2. Procedure for risk management in projects of electrical switchboard delivery

Source: own elaboration based on Courtot H. (1998). La gestion des risques dans les projets. Paris: Ed. Economica.

The fifth step in the proposed procedure of risk management in projects of electrical switchboard delivery is to define risk responses. In the last step, the Project Manager, after the completion of a particular project, should review the risk analysis and do post factum assessment. The proposed procedure of risk management was implemented in the .NET/C\# technology stack. If someone is interested in the application, she/he should contact the authors of this paper. Figure 3 shows the main window of the application with some sample data. The application is dedicated to project managers, but each time the Project Manager fills in data or edits it, the Quality Control Department and Technologist get notified and can check 
the correctness of the values. It is advised that the risk values are updated with a fixed frequency, for instance every week or every second week.

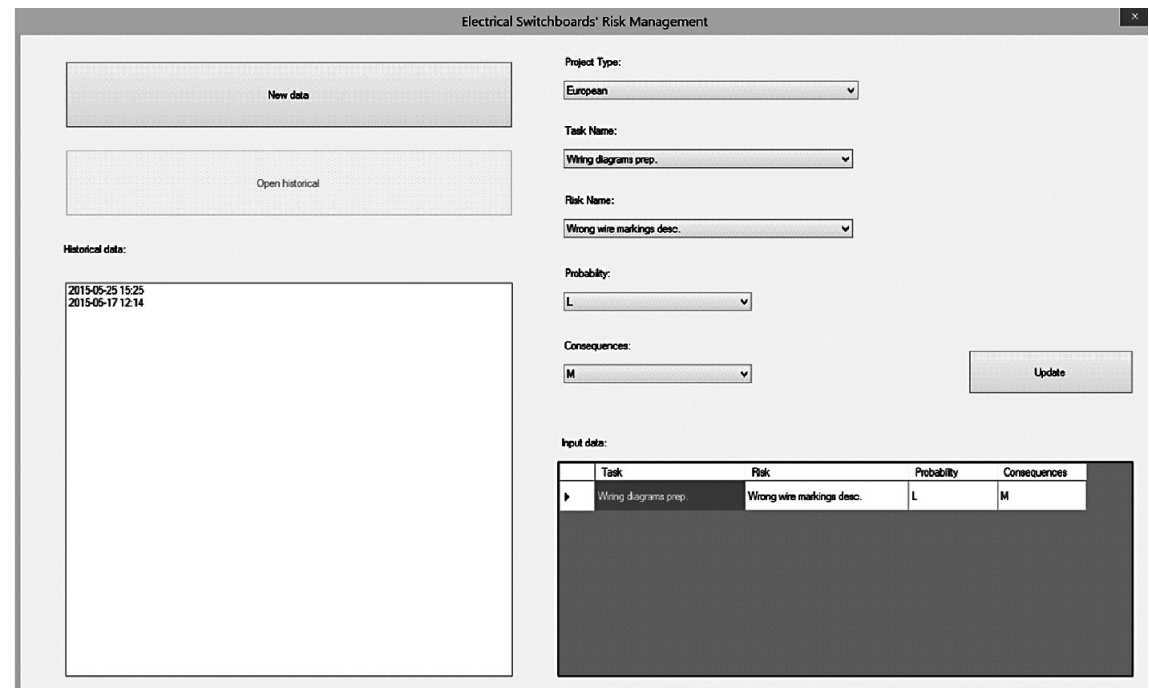

Figure 3. The main window of the application implemented for project risk management

Source: own elaboration.

\section{RESULTS}

The proposed procedure for risk management was implemented in a selected company and verified on several projects of electrical switchboard delivery.

As a result of using the proposed procedure of risk management in projects of electrical switchboard delivery we can underline:

- list of risks identified in projects of electrical switchboard delivery (Figure 4-17); for the $k$-th risk of the $i$-th project realisation stage and the $j$-th task from the WBS we use the following notation $R[i . j . k]$;

- list of risk responses which can be used in projects of electrical switchboard delivery (Table 1);

- current assessment of probability and consequences of the identified risks for the analysed company - obtained on the basis of past projects. 


\section{Task 1.1: Load list analysis}

- Wrong selection of devices to protect a specific load (R 1.1.1)

- Wrong selection of the size of cables for the feeders (R 1.1.2)

- Lack of specific load on the list (R 1.1.3)

Figure 4. Risks identified in the task of load list analysis Source: own elaboration.

In the task of load list analysis the most severe consequences can be assigned to the risk of wrong selection of equipment to protect a specific load. In this case it is necessary to buy new equipment which increases the cost of the project. The Project Manager is trying to return wrongly selected equipment to the seller, but the item can be returned for the price that is up to $70 \%$ of its initial value.

In the task of equipment list preparation the most severe consequences can be assigned to the risk of neglecting the IP Code (International Protection Marking). The IP Code classifies and rates the degree of protection provided against intrusion, dust, accidental contact, and water by mechanical casings and electrical enclosures. The IP Code is published by International Electrotechnical Commission as IEC standard 60529 .

Task 1.2: Equipment list preparation

- Neglecting IP Code (R 1.2.1)

- Neglecting working temperature (R 1.2.2)

- Neglecting requirements for short-circuit currents (R 1.2.3)

- Lack of analysis comparing the size of equipment with the space available in the switchboard (R 1.2.4)

Figure 5. Risks identified in the task of equipment list preparation Source: own elaboration.

Task 1.3: Wiring diagrams preparation

- Drawings of devices' terminals inconsistent with the specification of that equipment (R 1.3.1)

- Wrong description of colours and types of electric cables (R 1.3.2)

- Wrong definition of the size of electric cables (R 1.3.3)

- Wrong description of wire markings (R 1.3.4)

- Lack of work verification by the approver (R 1.3.5)

- Wrong hyperlinks between the pages of the wiring diagram (R 1.3.6)

Figure 6. Risks identified in the task of wiring diagrams preparation Source: own elaboration. 
In the task of wiring diagrams' preparation the most severe consequences can be assigned to the risk of wrong description of the colours and types of electric cables and the risk of wrong definition of their size. If it turns out that the switchboard was made using wrong cables, the whole work would need to be done again.

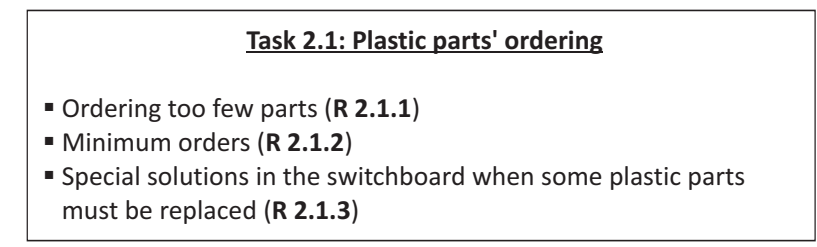

Figure 7. Risks identified in the task of plastic parts ordering Source: own elaboration.

In the task of plastic parts' ordering the most severe consequences can be assigned to the risk of ordering too few parts. This can result in production downtime which has a negative impact not only on the duration of the project, but also on its costs. If the company executing the project does not fit into the schedule, there will be financial penalties.

\section{Task 2.2: Steel parts ordering}

- Special solutions in the switchboard when some steel parts must be replaced ( $R$ 2.2.1)

- Wrong bending (R 2.2.2)

- Neglecting the information about the material, i.e. colour, thickness (R 2.2.3)

- Wrong painting of the steel parts (R 2.2.4)

- Wrong dimensioning of the steel parts (R 2.2.4)

Figure 8. Risks identified in the task of steel parts ordering Source: own elaboration .

In the task of steel parts' ordering the most severe consequences can be assigned to the risk of neglecting information about the material because it requires producing of a new part, which extends the duration of the project. 


\section{Task 2.3: Switchboard enclosure preparation}

- Preparation errors caused by incorrectly reading the instructions (R 2.3.1)

- Lack of steel or plastic parts (R 2.3.2)

- Placing the switchboard enclosure on an unsuitable base (R 2.3.3)

- Lack of foil between the switchboard enclosure and the palette (R 2.3.4)

Figure 9. Risks identified in the task of switchboard enclosure preparation Source: own elaboration.

In the task of the switchboard enclosure preparation the most severe consequences can be assigned to the risk of lack of steel or plastic parts because it causes delays in the switchboard enclosure preparation.

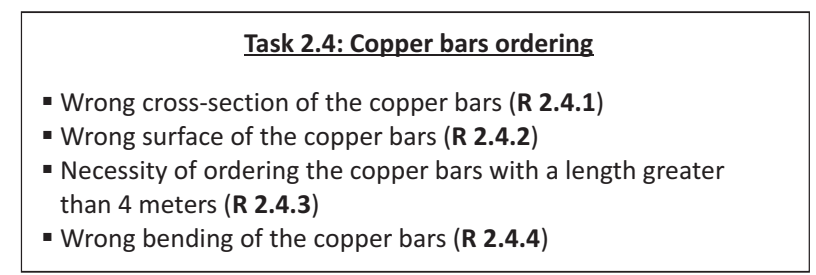

Figure 10. Risks identified in the task of copper bars' ordering Source: own elaboration.

In the task of the copper bars ordering the most severe consequences can be assigned to the risk of a wrong cross-section of the copper bars. If the cross-section is too small there is no electricity in the switchboard.

\section{Task 2.5: Electrical equipment ordering}

- Wrong quantity in the order (R 2.5.1)

- Ordering free-issue goods (R 2.5.2)

- Minimum orders (R 2.5.3)

- Ordering electrical equipment based on outdated prices (R 2.5.4)

Figure 11. Risks identified in the task of electrical equipment ordering Source: own elaboration.

In the task of electrical equipment ordering the most severe consequences can be assigned to the risk of wrong quantity in the order. The average delivery time of electrical equipment installed in a switchboard is three weeks and the absence of such an equipment can be discovered two weeks before the end of the project. The result is that the executor of the switchboard has to disassemble specific equipment 
at the customer's location and this is associated with additional costs of transportation to the customer (especially when it is a customer from the Middle East).

\section{Task 3.1: Copper bars installation}

- Screws not tightened (R 3.1.1)

- Phases L1, L2, L3 too close to each other (R 3.1.2

- Conductive copper bars too close to the construction (R 3.1.3)

Figure 12. Risks identified in the task of copper bars installation Source: own elaboration.

In the task of copper bars installation the most severe consequences can be assigned to the risk of screws not tightened. It may cause a failure of the entire switchboard. The problem is easy to miss by the Quality Control Department, because there are thousands of screws in one switchboard to be checked.

In the task of equipment installation the most severe consequences can be assigned to the risk of installing the equipment in a wrong position, because it causes duplication of work and therefore also extends the duration of the project.

Task 3.2: Equipment installation
- Fail to maintain appropriate distances between the devices that
generate heat (R 3.2.1)
- Installation of the equipment in a wrong position ( $\mathbf{R}$ 3.2.2)
- Damage of the equipment during the installation as a result
of using inappropriate tools (R $\mathbf{3 . 2 . 3})$

Figure 13. Risks identified in the task of equipment installation Source: own elaboration.

\section{Task 3.3: Wiring installation}

- Installation not compatible with the diagrams (R 3.3.1)

- Using a wrong ferrule for the specific size of cable (R 3.3.2)

- Using wrong colour of cable for the specific connection (R 3.3.3)

- Performing a too big bunch of cables that may prevent settling the cable in the cable duct (R 3.3.4)

- Wrong crimping of ferrules at the ends of the cables (R 3.3.5)

Figure 14. Risks identified in the task of wiring installation Source: own elaboration. 
In the task of wiring installation the most severe consequences can be assigned to the risk of installation that is not compatible with diagrams. This risk is usually discovered by the Quality Control Department. In this case the switchboard must be returned to production. Then another control is conducted and the duration of the project is extended.

\section{Task 3.4: Checking quality}

- Omitting errors occurring during the switchboard enclosure preparation (R 3.4.1)

- Omitting errors of wrong connection of the switchboard to the power supply (R 3.4.2)

- Wrong measurements, i.e. measurement of insulation resistance (R 3.4.3)

Figure 15. Risks identified in the task of checking out quality Source: own elaboration.

In the task of checking quality the most severe consequences can be assigned to the risk of omitting errors occurring during the switchboard enclosure preparation. In this case the customer receives a defective product and there is a need to improve it at the customer's facility. This situation causes the loss of reputation and travel expenses.

Task 3.5: Factory Acceptance Test
- Reasonable complaints from the customer (R 3.5.1)
- Lack of adequate competences of customer representatives
lack of awareness of dangers of working with energized equipment (R 3.5.2)
- Postponement of FAT because of logistic reasons (R 3.5.3)

Figure 16. Risks identified in the task of Factory Acceptance Test Source: own elaboration.

In the task of the Factory Acceptance Test the most severe consequences can be assigned to the risk of reasonable complaints from the customer, because customer's satisfaction is very important.

\section{Task 3.6: Packing and shipment}

- Selecting a package that is too small for the size of the switchboard (R 3.6.1)

- Wrong labeling of the package (R 3.6.2)

- Crash of the switchboard during packing on the truck (R 3.6.3)

- Lack of a vehicle adapted to the size of the package (R 3.6.4)

Figure 17. Risks identified in the task of packing and shipment Source: own elaboration. 
In the task of packing and shipment the most severe consequences can be assigned to the risk of selecting a package that is too small for the size of the switchboard. In this case the Project Manager has to order a new package which lasts about two weeks. Packing of the product is at the end of the schedule, so it always causes extending the duration of the project.

The list of risk responses for the identified risks is presented in Table 1.

Table 1. Risk responses in projects of electrical switchboard delivery

\begin{tabular}{|c|c|}
\hline Risk responses & Reduced risks \\
\hline $\begin{array}{l}\text { Verification of documentation by the } \\
\text { customer }\end{array}$ & $\begin{array}{l}\text { R 1.2.2; R 1.2.3; R 2.3.3; R 2.3.4; R 2.4.1; } \\
\text { R 2.4.2; R 3.5.1; R 3.6.2 }\end{array}$ \\
\hline Outsourcing of equipment & R 3.6 .4 \\
\hline Double verification of the documentation & $\begin{array}{l}\text { R 1.1.1; R 1.1.2; R 1.1.3; R 2.5.1; R 2.5.4; } \\
\text { R 3.1.1 }\end{array}$ \\
\hline Independent calculations by two employees & R 1.2 .3 \\
\hline Experienced employee assigned to the task & $\begin{array}{l}\text { R 1.1.1; R 1.1.2; R 1.1.3; R 1.2.1; R 1.2.2; } \\
\text { R 1.2.3; R 1.2.4; R 2.2.5; R 2.3.1; R 2.3.2; } \\
\text { R 3.2.1; R 3.2.2; R 3.2.3; R 3.3.1; R 3.3.2; } \\
\text { R 3.3.3; R 3.3.4; R 3.3.5; R 3.4.3; R 3.6.1; } \\
\text { R 3.6.3 }\end{array}$ \\
\hline Analysis of past projects & R 1.2 .4 \\
\hline Analysis of certification requirements & R 2.4.1; R 2.5.2; R 2.5.3; R 3.1.2; R 3.1.3 \\
\hline Keeping inventory & R 2.1 .1 \\
\hline $\begin{array}{l}\text { Analysis of modification before ordering } \\
\text { plastic parts }\end{array}$ & $\mathrm{R} 2.1 .3$ \\
\hline $\begin{array}{l}\text { Analysis of modification before ordering } \\
\text { metal parts }\end{array}$ & $\mathrm{R} 2.2 .1$ \\
\hline $\begin{array}{l}\text { Verifying proper understanding of the } \\
\text { diagram by the executor }\end{array}$ & $\mathrm{R} 2.2 .2$ \\
\hline Clarification of information in the contract & $\mathrm{R} 2.2 .3$ \\
\hline Employee training & $\begin{array}{l}\text { R 2.3.1; R 2.3.4; R 2.4.4; R 3.1.1; R 3.2.1; } \\
\text { R 3.2.2; R 3.2.3; R 3.3.1; R 3.3.2; R 3.3.3; } \\
\text { R 3.3.4; R 3.3.5 }\end{array}$ \\
\hline Control of the supply chain & R 2.3.2 \\
\hline
\end{tabular}


Table 1. cont.

\begin{tabular}{|l|l|}
\hline \multicolumn{1}{|c|}{ Risk responses } & \multicolumn{1}{c|}{ Reduced risks } \\
\hline $\begin{array}{l}\text { Attempting to optimise cuts made in the } \\
\text { elements }\end{array}$ & $\mathrm{R} 2.4 .3$ \\
\hline Using checklists & $\mathrm{R} 3.4 .1 ; \mathrm{R} 3.4 .2$ \\
\hline
\end{tabular}

Source: own elaboration.

\section{CONCLUSIONS}

Based on interviews with projects managers and the analysis of the documentation relating to completed projects of electrical switchboard delivery, we discovered that there are no formalised risk management procedures in a many Polish companies, which realise such projects. Therefore, we propose to use the traditional risk management procedure adapted for projects of electrical switchboard delivery. We verified it on the example of a selected company by using an automated tool implemented in the .NET/C\# technology stack.

Based on the completed studies, we can state that risk management is an important element of electrical switchboard delivery and should not be ignored in companies that realise such projects. We found out that there is a lack of proper documentation and archiving information in projects of electrical switchboard delivery, which means that knowledge is lost in situations when experienced employees leave the company and take the knowledge with them.

The proposed method allows collecting experience and enables easy access to the knowledge base about potential risks for the project which appeared in the past. In the case of a change of managers, it is easier to delegate this responsibility and inform newcomers. In the analysed company it could be seen that the gained experience influences the assessment of the risks in the projects. The positive is the fact that the probabilities of risks in subsequent projects were getting lower. This indicates that the analysed company learned from their own experience.

Future research will focus on improving the system and determining the feasibility of its widespread use. 


\section{REFERENCES}

Brown, E.M. \& Chong, Y.Y. (2000). Managing Project Risk. London: Person Education Limited.

Courtot, H. (1998). La gestion des risques dans les projets. Paris: Ed. Economica.

Davidson, F.J. (1995). Managing Projects In Organizations. How to Make the Best Use of a Time, Techniques and People? San Francisco: Jossey-Bass Publishers.

Forsbery, K., Mooz, H. \& Cotterman, H. (1996). Visualizing Project Management. New York: John Willley \& Sons.

Kaczmarek, T. (2006). Ryzyko i zarzadzanie ryzykiem. Ujęcie interdyscyplinarne. Warszawa: Centrum Doradztwa i Informacji Difin.

Kaen, F.R. (2000). Risk Management: A Corporate Governance Perspective in Risk, Challenge and Opportunity. Berlin: Springer.

Kleim, R.I. \& Ludin, I.S. (1997). Reducing Project Risk. Aldershot: Gower.

Maylor, H. (1996). Project Management. London: Pitman Publishing.

Pfeffer, J. (1956). Insurance and Economic Theory. Homewood, Illinois: Irvin Inc.

Pritchard, C.L. (2012). Risk Management. Concepts and Guidance. Boca Raton: CRC Press.

PMI [Project Management Institute] (2008). A Guide to the Project Management Body of Knowledge. 4th Edition, Pennsylvania.

Project Management for Instructional Designers, http://pm4id.org/11/1/ (access: 30.07.2015).

Ptaszyńska, E. (2012). Metoda zarzadzania ryzykiem projektów. $\mathrm{PhD}$ thesis, supervisor: prof. D. Kuchta. Wrocław.

Rogowski, W., Michalczewski, A. (2005). Zarzadzanie ryzykiem w przedsięwzięciach inwestycyjnych. Kraków: Oficyna Ekonomiczna.

Trocki, M. \& Grucza, B. (2007). Zarzadzanie projektem europejskim. Warszawa: Polskie Wydawnictwo Ekonomiczne.

Samuelson, W.F. \& Marks S.G. (2006). Managerial Economics. 5th Edition. New York: John Wiley \& Sons.

Troelsen, A. (2012). Pro C\# 5.0 and the .Net 4.5 Framework. 6th Edition. New York: Apress.

Willett, A.H. (1901). The Economic Theory of Risk and Insurant. Columbia University Studies.

Zachorowska, A. (2006) Ryzyko działalności inwestycyjnej przedsiębiorstw. Warszawa: PWE. 


\title{
ZARZĄDZANIE RYZYKIEM W PROJEKTACH DOSTAWY ROZDZIELNIC ELEKTRYCZNYCH
}

\begin{abstract}
Abstrakt
Tło badań. W projektach dostawy rozdzielnic elektrycznych można zidentyfikować wiele ryzyk, najczęściej bardzo dotkliwych w swoich konsekwencjach, gdyż są to projekty wysokobudżetowe. Nasze badania wykazuja, że wiele polskich firm realizujacych tego typu projekty nie stosuje sformalizowanych procedur zarządzania ryzykiem.
\end{abstract}

Cel badań. W związku z powyższym proponujemy skorzystać z tradycyjnej procedury zarządzania ryzykiem i zaadaptować ją do specyfiki projektów dostawy rozdzielnic elektrycznych, co w artykule zweryfikowano na przykładzie wybranego przedsiębiorstwa.

Metodologia. Wykorzystujemy następujące metody badawcze: analiza dokumentacji dotyczącej zrealizowanych projektów dostawy rozdzielnic elektrycznych, wywiady z kierownikami tego typu projektów, analiza literatury.

Kluczowe wnioski. W rezultacie uzyskaliśmy: Strukturę Podziału Pracy (SPP), listę zidentyfikowanych ryzyk, listę proponowanych reakcji na ryzyko, aplikacje komputerową wspierającą zarządzanie ryzykiem w projektach dostawy rozdzielnic elektrycznych. Na podstawie przeprowadzonych badań stwierdzamy, że zarządzanie ryzykiem jest ważnym elementem zarządzania projektami dostawy rozdzielnic elektrycznych i nie powinno być pomijane przez firmy realizującego tego typu projekty.

Słowa kluczowe: zarządzanie projektem, zarządzanie ryzykiem, projekty dostawy rozdzielnic elektrycznych. 